\title{
APPLICATION OF FENTON'S REAGENT IN THE TEXTILE WASTEWATER TREATMENT UNDER INDUSTRIAL CONDITIONS
}

\section{ZASTOSOWANIE ODCZYNNIKA FENTONA DO OCZYSZCZANIA ŚCIEKÓW WŁÓKIENNICZYCH W WARUNKACH PRZEMYSŁOWYCH}

\begin{abstract}
Application of reactive dyes is very popular in textile industry as these dyestuffs are characterized by good fastness properties. Constapel et al in 2009 estimated the production of this type of dyes for over $140,000 \mathrm{Mg}$ /year. The reactive dyes are mostly (50\%) employed for coloration of cellulosic fibers, however they can also be applied on wool and nylon. Unfortunately, they possess a low degree of fixation $(50 \div 90 \%)$, since the functional groups also bond to water, creating hydrolysis and the excess of dyes applied cause a colored pollution of aqueous environment. Moreover, dyeing process requires the use of: electrolytes in the form of aqueous solutions of $\mathrm{NaCl}$ or $\mathrm{Na}_{2} \mathrm{SO}_{4}$ in the concentration up to $100 \mathrm{~g} / \mathrm{dm}^{3}$, alkaline environment $(\mathrm{pH}>10)$ and textile auxiliary agents (including detergents). Therefore, the wastewater generated during the reactive dyeing processes is characterized by high salinity, $\mathrm{pH}$ value and color, and due to low value of the $\mathrm{BOD}_{5} / \mathrm{COD}$ ratio are nonbiodegradable. The successful methods of textile wastewater treatment could be Advanced Oxidation Processes (AOPs), amongst which the Fenton reagent seems to be most promising as it is the cheapest and easy in use. Based on the newest literature survey it was found that many successful tests with Fenton reaction were performed mainly in decolorization. However, not enough attention was devoted to decolorization of real industrial wastewater containing dyes, detergents and salts $\mathrm{NaCl}$, or $\mathrm{Na}_{2} \mathrm{SO}_{4}$. The experiments carried out in a laboratory scale were focused on the impact of $\mathrm{NaCl}$ and textile auxiliary agent (liquid dispersing and sequestering agent) on an inhibition of decolorization process by Fenton's reagent. The objects of the investigation were synthetic mixtures simulating the composition of real textile wastewater as well as the real industrial wastewater generated in the reactive dyeing. The inhibition of the Fenton decolorization in the presence of $\mathrm{NaCl}$ and liquid dispersing and sequestering agent was demonstrated. Additional experiments using pulse radiolysis were carried out in order to confirm the inhibition of chloride in the decolorization process.
\end{abstract}

Keywords: Fenton's reagent, textile wastewater, decolorization, inhibition

\section{Introduction}

A full range of bright colors, stable covalence bond to the fiber, providing good fastness of dyeing and relatively easy synthesis - these properties make reactive dyes so

\footnotetext{
${ }^{1}$ Faculty of Process \& Environmental Engineering, Technical University of Lodz, ul. Wólczańska 213, 90-924 Łódź, Poland, phone: +48 426313715

${ }^{2}$ Textile Research Institute, ul. Brzezińska, 5/7, 92-103 Łódź, Poland, phone: +48 426163111 , email: zylla@iw.lodz.pl

*Corresponding author: stanleda@p.lodz.pl
} 
popular in textile industry [1]. Constapel et al [2] estimated the annual production of these types of dyestuff for over 140,000 Mg, while Ahmed and El-Shishtway [3] announce that $50 \%$ of all cellulose fibers is dyed with reactive dyes, and only $17 \%$ with vat dyes, $16 \%$ with direct dyes, $7 \%$ with sulfur dyes, also $7 \%$ with indigo dyes and $3 \%$ with glacial dyes. Reactive dyes are mostly used to dye cellulose fibers, however there are also groups of reactive dyes dedicated to wool and polyamide. Unfortunately, despite those advantages and common use, reactive dyes are marked by low degree of fixation, between 50 and $90 \%$, depending on the assortment. It means, the excess of dye, used in industrial dyeing process, does not bind to the fibers and in the hydrolyzed form is expelled to the sewage, causing higher contamination of aqueous environment. The fact that the process of reactive dyeing requires special technology also has to be taken into consideration. A fixation of reactive dye onto fiber is possible, when an electrolyte $\mathrm{NaCl}$ or $\mathrm{Na}_{2} \mathrm{SO}_{4}$ is used in dye bath, strong alkaline $\mathrm{pH}$ is produced and auxiliary surface active agents (SAA) are applied. The consumption of dyestuff in process of reactive textile dyeing amounts on average to $0.5 \div 80 \mathrm{~g} / \mathrm{kg}$ textiles, organic auxiliary agents up to $30 \mathrm{~g} / \mathrm{kg}$ textiles, inorganic auxiliary agents $30 \div 250 \mathrm{~g} / \mathrm{kg}$ textiles and electrolyte $90 \div 1500 \mathrm{~g} / \mathrm{kg}$ textiles. Therefore, the wastewater generated in reactive dyeing process is marked by high salinity and coloration, high $\mathrm{pH}$ value and SAA presence. Moreover, textile wastewater is characterized by high COD and low BOD value which makes it non-biodegradable.

A way of purification of this kind of wastewater could be AOPs methods (Advanced Oxidation Processes), amongst which the Fenton reagent is worth of consideration, as it is not expensive and easy in use. Fenton's reagent is a method of generating hydroxyl radicals $\left(\mathrm{HO}^{\circ}\right)$ by using reaction of hydrogen peroxide decomposition catalyzed by ferrous ions $\mathrm{Fe}^{2+}$. The application of an oxidizer with high redox potential (for $\mathrm{HO}^{\bullet} 2.81 \mathrm{~V}$ ) generated under in situ conditions, with Fenton's reaction, enables decomposition of low biodegradable substances, including dyestuff used in textile industry.

According to the newest literature reports a lot of successful tests were performed, mostly in decolorization of dye solution used in textile industry, not only of reactive dyes. $\mathrm{Xu}$ et al [4], Papic et al [5], Kusic et al [6], Tantak and Chaudhari [7] and Arslan-Alaton et al [8] worked on decolorization of reactive dye solution with the use of Fenton's reagent. Wang et al [9], Gulkaya et al [10], Bianco et al [11] worked on decolorization of real industrial wastewater. These studies were focused on optimization of the method regarding color reduction, reduction of TOC (Total Organic Carbon) and comparison of working effects of $\mathrm{Fe}^{2+} / \mathrm{H}_{2} \mathrm{O}_{2}$ and $\mathrm{Fe}^{2+} / \mathrm{H}_{2} \mathrm{O}_{2} / \mathrm{UV}$.

The aim of the present publication is to show the inhibition impact of $\mathrm{NaCl}$ and SAA, present in real industrial wastewater, on its decolorization. Similar tests have already been performed by Alnuaimi et al [12], Riga et al [13] and Arslan-Alaton et al [14] and revealed the inhibition impact of salt on Fenton's reaction. Those tests included the impact of different kinds of salts on decolorization process of dye solution with Fenton's reagent, however the impact of SAA has not been examined yet. Moreover, the highest salt concentration $(\mathrm{NaCl})$ used in these tests was $15 \mathrm{~g} / \mathrm{dm}^{3}$, while in industrial dyeing practice it can reach up to $100 \mathrm{~g} / \mathrm{dm}^{3}$. Therefore, further study on this matter, including higher salt concentration and SAA presence, concentrated on the examination of both synthetic mixtures simulating the composition of real textile wastewater and real wastewater generated in reactive dyeing process, seems to be justified. 


\section{Experimental}

\section{Tested material}

Three azo dyes, including two reactive and one acid dye, were used in this paper (Table 1). C.I. Reactive Black 5 is known in commercial form as Setazol Black DPT supplied by Setas Kimya. Molecular weight of Reactive Black 5 is $991.82 \mathrm{~g} / \mathrm{mol}$ and the maximum absorbance for this dye was observed at wavelength $\lambda=596 \mathrm{~nm}$. Acid Red 27 and Reactive Blue 81 dyes (Boruta Color, Poland) in purified form, without fillers, were used in pulse radiolysis studies.

Table 1

List of dyes tested in the experiment

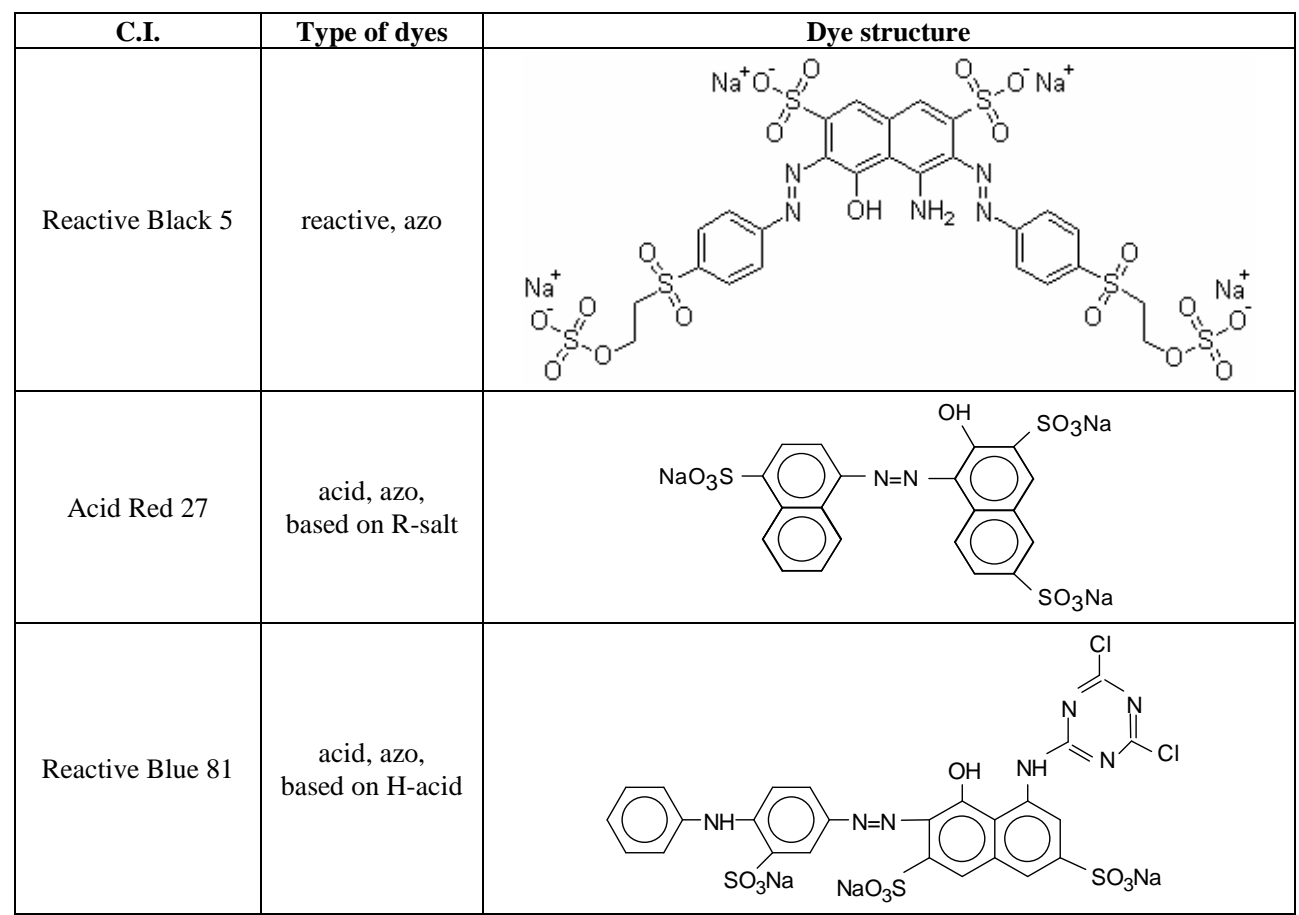

\section{Application of Fenton's reagent}

$\mathrm{FeSO}_{4} \cdot 7 \mathrm{H}_{2} \mathrm{O}$, hydrogen peroxide $-\mathrm{H}_{2} \mathrm{O}_{2}$ conc. $30 \%, \mathrm{H}_{2} \mathrm{SO}_{4}$ conc. $94 \%$ - aqueous solution 1:10, $\mathrm{NaOH}, \mathrm{NaCl}$, Perigen LDR supplied by Textilchemie Dr Petry GmbH liquid dispersing and sequestering agent based on naphthalene sulphonic acid condensate and carboxylates have been used. The aqueous solutions of dyes and auxiliary agents have been prepared by Dosorama machine provided by Technorama. The dyestuff in a hydrolyzed form has been used, since it is present in this form in textile wastewater. The hydrolysis of dye solution has been performed in water bath at temperature $80^{\circ} \mathrm{C}$ during 2 hours, at $\mathrm{pH}$ 12. Initial dye concentration in the simulated industrial wastewater mixtures has been fixed, basing on earlier experiments, on $200 \mathrm{mg} / \mathrm{dm}^{3}$. 
The color of the dye water solution has been measured by defining the absorbance with maximum absorbance of the dye. The kinetics of decolorization of water dye solution with Fenton's reagent has been examined by measuring the absorbance with transient absorption spectrophotometer Helios, delivered by Thermo company, with constant, automatic tests collection and flow cell. Decolorization has been carried out for the three objects: aqueous solutions of BDPT dye only, simulated lab mixtures imaging the composition of real wastewater (BDPT dye solution with $\mathrm{NaCl}$ and Perigen LDR) and for real wastewater after dyeing process. Tests have been taken in textile testing laboratory under conditions of normal alternative climate according to ISO 139:2005, point 3.2 standards.

\section{Pulse radiolysis}

Kinetic reaction of selected dyes with hydroxyl radicals and ion-radicals $\mathrm{Cl}_{2}^{--}$was determined by pulse radiolysis. The aim of this study was to examine the extent to which chloride ion-radicals $\mathrm{Cl}_{2}^{--}$may affect the efficiency of Fenton process. Chloride ion-radicals can be followed spectrophotometrically in the wavelength range $\lambda=300$ to $400 \mathrm{~nm}$. The spectrum has a maximum absorbance at the wavelength $\lambda=340 \mathrm{~nm}$ [15]. In order to obtain the chloride ion-radicals, dye solutions were acidified with $\mathrm{HCl}$, the $\mathrm{HCl}$ concentration in the solution was $0.1 \mathrm{M}$. To do the kinetic study by pulse radiolysis method, a linear electron accelerator ELU-6E was used, in which pulses with duration from 2 to $17 \mathrm{~ns}$ were available. The energy of accelerated electrons was $\mathrm{E}_{\max }=8 \mathrm{meV}$ and the maximum current in the pulse reached the value of $15 \mathrm{~A}$. Direct observations of formation and decay of radiolysis products were conducted on the basis of spectrophotometric analysis. Measurements were made with time scale from nanoseconds to seconds in the wavelength range from 300 to $750 \mathrm{~nm}$. The relative changes of absorbance were recorded with $15 \mathrm{~nm}$ step. Both in the case of hydroxyl radicals and chloride ion-radicals, the solution was saturated with $\mathrm{N}_{2} \mathrm{O}$ before the measurement session for 30 minutes. During the measurements $\mathrm{N}_{2} \mathrm{O}$ surrounded the system, preventing it from the access of oxygen. The solution was placed in a flow system which was equipped with a valve controlled automatically from the accelerator control room. The valve opened up after each shot of electron beam in the sample $\left(1 \mathrm{~cm}^{3}\right)$ which allowed us to introduce of a fresh portion of solution before the next shot. The obtained kinetic runs for each wavelength in a measurement series were normalized to a predetermined dose and light intensity. These calculations were performed automatically by a computer program. The spectrum of the reaction products was made for selected time intervals based on the obtained results.

\section{Results and discussion}

\section{Effect of pH on Fenton process}

Natural $\mathrm{pH}$ value after decolorization process reaches 11 or even 12 . However, the decomposition reaction of $\mathrm{H}_{2} \mathrm{O}_{2}$ is catalyzed most efficiently by $\mathrm{Fe}^{2+}$ ions in water solutions with $\mathrm{pH}$ value between 2 and 3. In order to verify this, the decolorization of BDPT dyestuff proceeded at $\mathrm{pH}$ values equal to 2 and 3. For comparison, also for two other reactive azo dyestuffs (YKHL - Synozol Yellow KHL and YHB - Synozol Yellow HB) the same test was performed which is presented in Figure 1. The decolorization with Fenton's reagent for all examined dyestuff solutions proceeded the fastest with $\mathrm{pH}$ value equal to 3 . Therefore, 
further tests have been performed at $\mathrm{pH}$ equal to 3 . In all tests the $\mathrm{pH}$ value of examined samples was set with $\mathrm{H}_{2} \mathrm{SO}_{4} 1: 10$ solution.

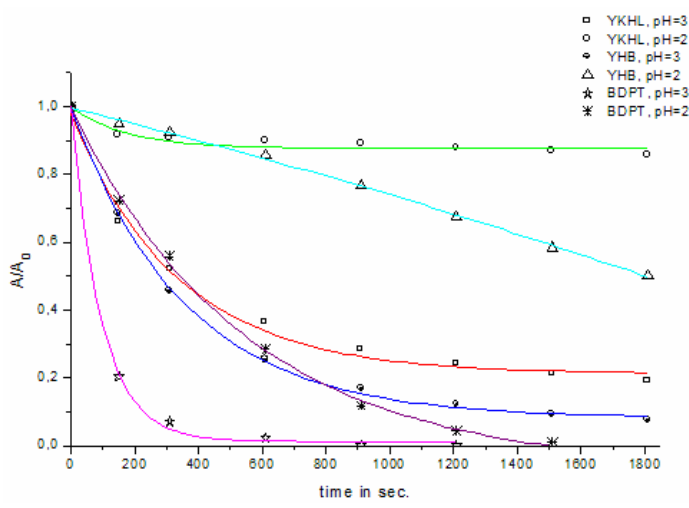

Fig. 1. Decolorization of aqueous solutions of dyestuffs: YKHL, YHB, BDPT with dyestuff concentration $200 \mathrm{mg} / \mathrm{dm}^{3}$ and $75 \mathrm{mg} \mathrm{Fe} \mathrm{Fe}^{2+} / 750 \mathrm{mg} \mathrm{H}_{2} \mathrm{O}_{2}$ at $\mathrm{pH}$ value equal to 2 and 3

\section{Effect of ferrous dosage and $\mathrm{Fe}^{2+}: \mathrm{H}_{2} \mathrm{O}_{2}$ ratio}

In order to find an optimal dosage and reagent ratio assuring effective decolorization process, tests for aqueous solution of BDPT have been performed. The concentrations of $\mathrm{FeSO}_{4}$ within the range $25 \div 100 \mathrm{mg} / \mathrm{dm}^{3}$ and reagent ratio $\mathrm{FeSO}_{4}: \mathrm{H}_{2} \mathrm{O}_{2}$ 1:5 and 1:10 have been applied. The results obtained for the solutions are shown in Figure 2. In each case a higher degree of color reduction has been reported for the reagents ratio 1:10 which has been chosen for further tests of BDPT decolorization with $\mathrm{FeSO}_{4}$ concentration amounting $75 \mathrm{mg} / \mathrm{dm}^{3}$. The degree of color reduction of the aqueous solution of BDPT exceeded $99 \%$.

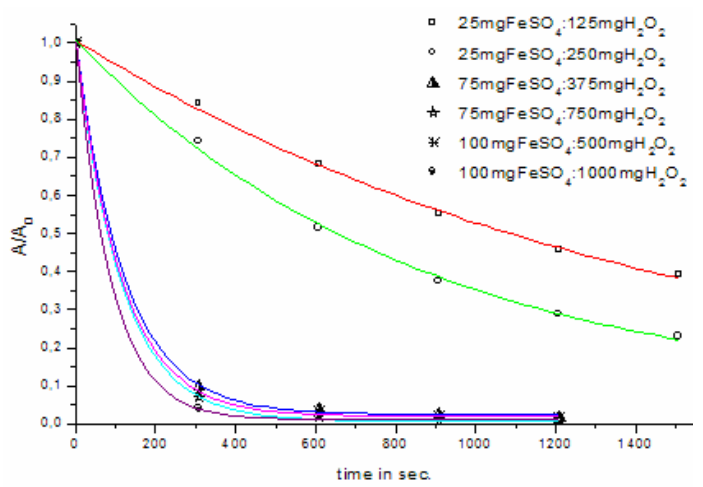

Fig. 2. Dependence of decolorization of aqueous solutions of BDPT dyestuff on $\mathrm{FeSO}_{4}$ dose

It was found that irrespective of the value of $\mathrm{Fe}^{2+}: \mathrm{H}_{2} \mathrm{O}_{2}$ mass ratio, the degree of pollution reduction expressed in COD (Chemical Oxygen Demand) and TOC after the oxidation process usually did not exceeded $30 \%$ for COD and $20 \%$ for TOC (cf. Figure 3 ). 


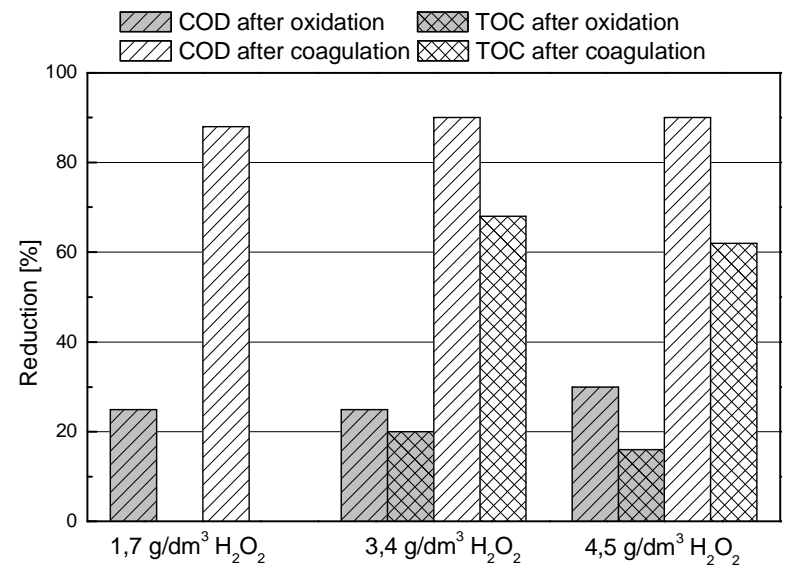

Fig. 3. The degree of COD and TOC reduction in the oxidation and coagulation process of the model textile wastewater for different $\mathrm{H}_{2} \mathrm{O}_{2}$ concentrations. Concentration of $\mathrm{FeSO}_{4} \cdot 7 \mathrm{H}_{2} \mathrm{O}=3.0 \mathrm{~g} / \mathrm{dm}^{3}$

Most of the pollution (60\%) was removed in the precipitation process of iron ions. After the precipitation process treated wastewater typically contained about $10 \%$ of pollutants in the untreated wastewater. Low degree of COD and TOC reduction with total decolorization of wastewater is quite often observed for the chemical oxidation methods. In many research works the authors report that the application of advanced oxidation methods causes a COD reduction of textile wastewater up to $50 \%$ [16].

\section{Effect of $\mathrm{NaCl}$ on Fenton process}

The same conditions of Fenton reaction as for aqueous solution of BDPT (75 mg FeSO $4 / \mathrm{dm}^{3}$ and reagent ratio $\mathrm{FeSO}_{4}: \mathrm{H}_{2} \mathrm{O}_{2}$ 1:10) have been used for decolorization of BDPT dyestuff solution containing 1, 5, 10, 20, 40 and $80 \mathrm{~g} \mathrm{NaCl} / \mathrm{dm}^{3}$. As it can be seen in Figure 4 , only for $1 \mathrm{~g} \mathrm{NaCl} / \mathrm{dm}^{3}$ no meaningful decrease of decolorization efficiency appeared compared with the tests without $\mathrm{NaCl}$. However, color reduction for a sample including $10 \mathrm{~g} \mathrm{NaCl} / \mathrm{dm}^{3}$ amounted already to $63 \%$, and for the one including $80 \mathrm{~g} \mathrm{NaCl} / \mathrm{dm}^{3}-40 \%$ after $45 \mathrm{~min}$.

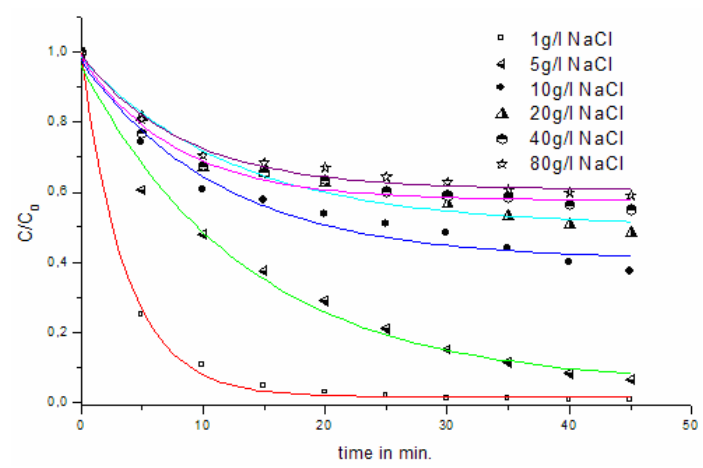

Fig. 4. Dependence of decolorization of aqueous solutions of BDPT dyestuff on $\mathrm{NaCl}$ concentration 
The impact of $\mathrm{NaCl}$ on decolorization efficiency can be explained as follows. In the presence of excess $\mathrm{Cl}^{-}$ions due to the reaction of $\mathrm{HO}^{\circ}$ radicals with $\mathrm{Cl}^{-}$ions the ion-radicals $\mathrm{Cl}_{2}^{\circ-}$ are produced which possess much lower oxidative potential than $\mathrm{HO}^{\circ}$ radicals [17].

The mechanism of hydroxyl radical scavenging action by chloride ions can be summarized as follows:

$$
\begin{gathered}
\mathrm{HO}^{\bullet}+\mathrm{Cl}^{-} \stackrel{k_{1}}{\longrightarrow} \mathrm{HOCl}^{\bullet-} \\
k_{1}=3 \cdot 10^{9} \mathrm{dm}^{3} / \mathrm{mol} \mathrm{s} \\
\mathrm{HOCl}^{\bullet}-+\mathrm{H}^{+} \longrightarrow \mathrm{H}_{2} \mathrm{O}+\mathrm{Cl}^{\bullet} \\
\mathrm{Cl}^{\bullet}+\mathrm{Cl}^{-} \stackrel{k_{2}}{\longrightarrow} \mathrm{Cl}_{2}^{\bullet-} \mathrm{Cl}_{2}^{\bullet-} \\
k_{2}=2 \cdot 10^{10} \mathrm{dm}^{3} / \mathrm{mol} \mathrm{s}
\end{gathered}
$$

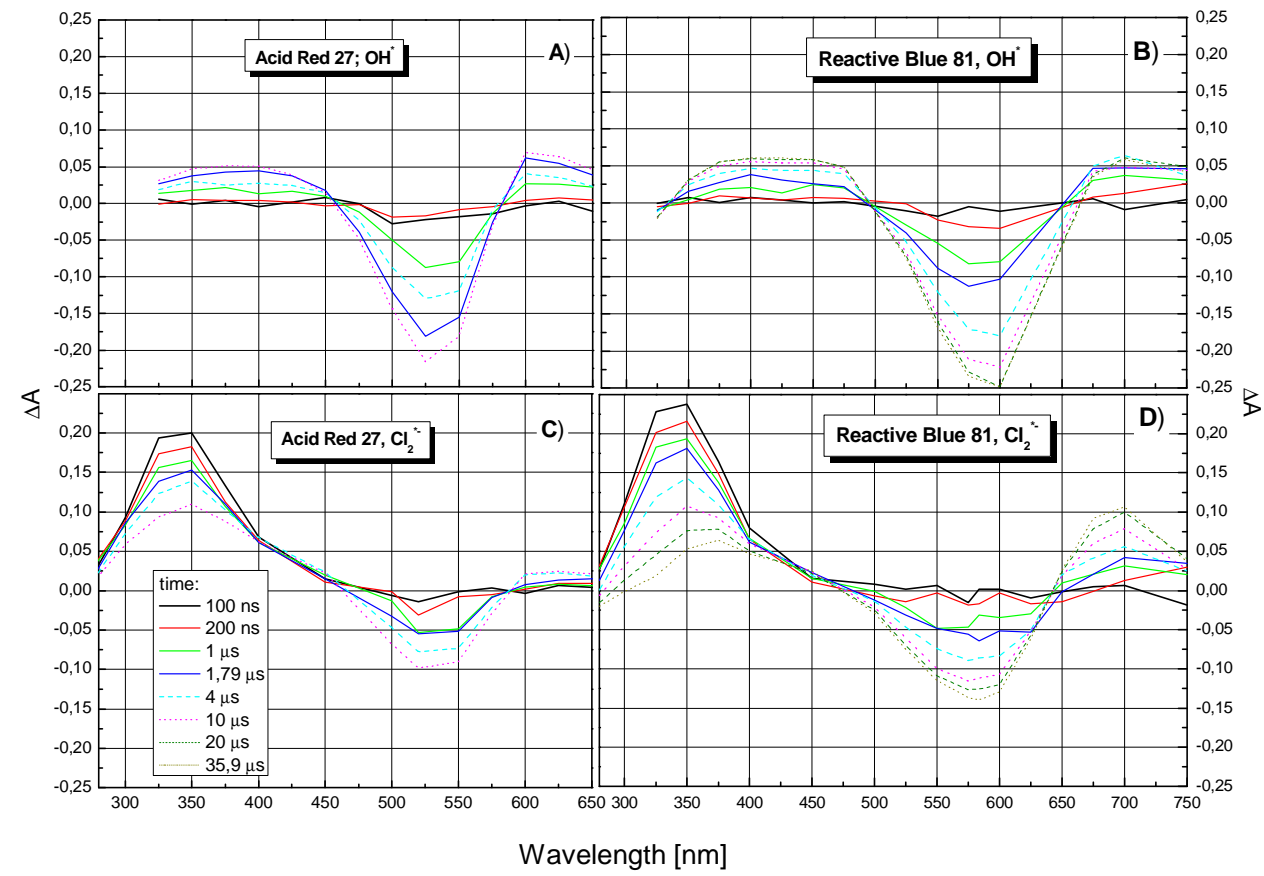

Fig. 5. Spectrum changes of selected azo dyes, Acid Red 27 and Reactive Blue 81, in the pulse radiolysis with chloride ion-radicals for time interval $40 \mu \mathrm{s}$; initial dye concentration was $25 \mathrm{mg} / \mathrm{dm}^{3}$

Rate constants of ion-radicals $\mathrm{HOCl}^{--}$and $\mathrm{Cl}_{2}^{--}$formation in reaction (1) and (3) are known and their values are typical for radical reactions, reaction constant $k_{1}=3.0 \cdot 10^{9} \mathrm{dm}^{3} / \mathrm{mol} \mathrm{s}$ (at $\mathrm{pH}=2 \div 3$ ); reaction constant $k_{2}=2 \cdot 10^{10} \mathrm{dm}^{3} / \mathrm{mol} \mathrm{s}$ [14]. Using 
pulse radiolysis method the measurement series of reaction rate of dye molecules with ion-radicals $\mathrm{Cl}_{2}^{\bullet-}$ were performed (Fig. 5B and 5C).

Based on the absorbance curve changes at different wavelengths the spectrum of aqueous solution of dye for different reaction times was obtained. By tracking spectrum changes up to $2 \mu \mathrm{s}$ a rapid absorbance increase may be observed at the wavelength $\lambda=340 \div 350 \mathrm{~nm}$. As is known from the literature, chloride ion-radicals absorb light in the wavelength range $\lambda=250$ to $400 \mathrm{~nm}$, while at $\lambda=340 \mathrm{~nm}$ the spectrum has its maximum [15]. Therefore, it can be concluded that the appearance of the peak at $\lambda=340 \mathrm{~nm}$ results from the formation of chloride ion-radicals. During decay of absorbance in visible light range, the decay of absorbance at the wavelength $\lambda=340 \mathrm{~nm}$ was reported.

Figure 6 shows the kinetic curves of color decay during pulse radiolysis with chloride ion-radicals and hydroxyl radicals. It follows from Figure 6 that the dye decolorization process occurs much more slowly with the participation of chloride ion-radicals, regardless of the tested dyes.

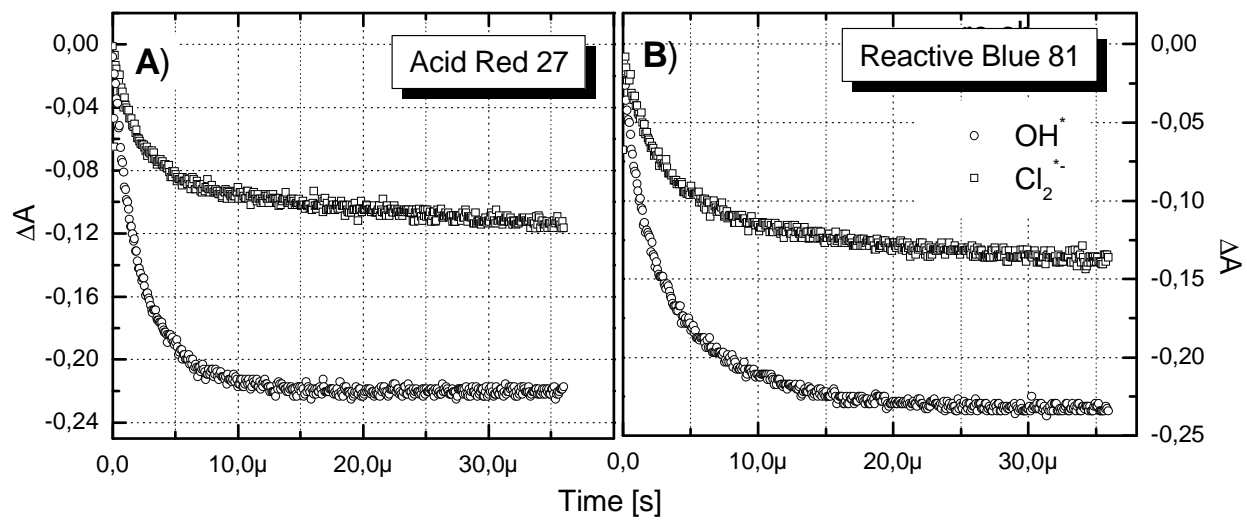

Fig. 6. Time-dependent decolorization of dye during reaction with hydroxyl radicals and chloride ion-radicals with pulse radiolysis of: A) Acid Red 27; B) Reactive Blue 81; initial dye concentration $25 \mathrm{mg} / \mathrm{dm}^{3}$

Based on experimental data obtained in the $2 \mu$ s time interval, reaction rate constants of dye molecules with chloride ion-radicals were determined. Based on the dependence of rate constant of pseudo-first order reaction from the initial dye concentration the value of appropriate reaction rate constant was determined (Table 2). Comparing the rate constants of decolorization of dye in the reaction with hydroxyl radicals and chloride ion-radicals it can be concluded that reaction involving $\mathrm{Cl}_{2}^{-}$is much slower.

Reaction rate of hydroxyl radicals with chloride ions $\mathrm{Cl}^{-}\left(k_{1}=3.0 \cdot 10^{9} \mathrm{dm}^{3} / \mathrm{mol} \mathrm{s}\right)$ is comparable to the rate of reaction of these radicals with the dye Reactive Blue 81 molecules ( $\left.k=1.98 \cdot 10^{9} \mathrm{dm}^{3} / \mathrm{mol} \mathrm{s}\right)$. It can be assumed that the mechanism of decolorization process can proceed either by $\mathrm{OH}^{*}$ radicals and $\mathrm{Cl}_{2}^{--}$ion-radicals. The competitiveness of these reactions depends on the initial concentration of reactants. With a large excess of chloride 
ions relative to the dye molecules, the decolorization process will be conducted mainly through chloride ion-radicals. In this paper the concentration of chloride ions was in large excess to the concentration of dye molecules.

Reaction rate constants of dyes with hydroxyl radicals and ion-radicals $\mathrm{Cl}_{2}^{\bullet-}$

\begin{tabular}{|c|c|c|}
\hline Type of dye & $\begin{array}{c}\text { Rate constant with } \mathbf{O H} \\
{\left[\mathbf{d m}^{\mathbf{3}} / \mathbf{m o l} \mathbf{~ s}\right]}\end{array}$ & $\begin{array}{c}\text { Rate constant with } \mathbf{C l}_{\mathbf{2}}^{\bullet-} \\
{[\mathbf{d m} / \mathbf{m o l ~ s}]}\end{array}$ \\
\hline Reactive Blue 81 & $1.98 \cdot 10^{9}$ & $8.98 \cdot 10^{8}$ \\
\hline Acid Red 27 & $9.17 \cdot 10^{9}$ & $6.51 \cdot 10^{8}$ \\
\hline
\end{tabular}

As it is shown in Table 2, the reaction rate constants of dye with $\mathrm{Cl}_{2}^{\bullet-}$ ion radicals are one order of magnitude lower than the rate constant of reaction with hydroxyl radicals. However, it seems that so significant inhibition of decolorization process is not due only to slower reaction kinetics through $\mathrm{Cl}_{2}^{--}$ion-radicals. Observing the kinetic curves in a longer time interval $(40 \mu \mathrm{s})$ (Fig. 6A and 6B) it can be noticed that the final degree of conversion of dye is much lower than in the case of reaction with hydroxyl radicals. So significant inhibition may indicate the presence of chloride ion-radicals competitive reactions which are faster than the reaction of dye with $\mathrm{Cl}_{2}^{\bullet-}$ ion-radicals, as rate constant for the former one is an order of magnitude bigger. Chloride ion-radicals can react with each other, or create free chlorine molecules.

The obtained results make it possible to explain the case of significant inhibition of Fenton process, where high concentration of $\mathrm{Cl}^{-}$ions in the reaction medium is observed. Due to the fact that the Fenton process proceeds mainly by hydroxyl radicals, it can be assumed with high probability that these radicals change into the $\mathrm{Cl}_{2}^{\bullet-}$ form in the presence of $\mathrm{Cl}^{-}$ions.

The adverse effect of chloride ions also contributes to the fact that as a source of iron ions $\mathrm{FeSO}_{4}$ is preferred to $\mathrm{FeCl}_{2}$. Table 3 gives rate constants of the reaction of iron ions $\mathrm{Fe}^{2+}$ with $\mathrm{H}_{2} \mathrm{O}_{2}$ molecules [17]. Reaction rate constants for $\mathrm{FeSO}_{4}$ are similar to these published by other authors [18]. However, rate constants for the reaction with $\mathrm{FeCl}_{2}$ are lower by half than the constants obtained in the reaction with $\mathrm{FeSO}_{4}$.

Table 3

Reaction rate constants of dye decolorization during Fenton process $\left[\mathrm{dm}^{3} / \mathrm{mol} \mathrm{s}\right]$

\begin{tabular}{|c|c|c|}
\hline Dye & FeSO$_{\mathbf{4}} \cdot \mathbf{7} \mathbf{H}_{\mathbf{2}} \mathbf{O}$ & $\mathbf{F e C l}_{2} \cdot \mathbf{4} \mathbf{H}_{\mathbf{2}} \mathbf{O}$ \\
\hline Acid Red 27 & 106 & 56 \\
\hline Reactive Blue 81 & 74 & 44 \\
\hline
\end{tabular}

\section{Effect of Perigen LDR addition on Fenton Process}

After increasing the $\mathrm{FeSO}_{4}$ dose up to $200 \mathrm{mg} / \mathrm{dm}^{3}$ and keeping the ratio $\mathrm{FeSO}_{4}: \mathrm{H}_{2} \mathrm{O}_{2}=1: 10$, the test has been repeated for samples of BDPT solution containing $0.5,1.0$ and $2.0 \mathrm{~g} / \mathrm{dm}^{3}$ of auxiliary agent - Perigen LDR. In the case of samples containing 0.5 and $1.0 \mathrm{~g} / \mathrm{dm}^{3}$ Perigen LDR the Fenton reaction enabled $99 \%$ color reduction, however for the samples containing $2.0 \mathrm{~g} / \mathrm{dm}^{3} \mathrm{LDR}$ the degree of color reduction decreased to $75 \%$ 
after 45 min, which was shown in Figure 7. The presence of surfactants in the concentration above the Critical Micelle Concentration (CMC) causes emulsification of dyestuff molecule shielding it against the attack of radicals, which in consequence decreased the efficiency of decolorization.

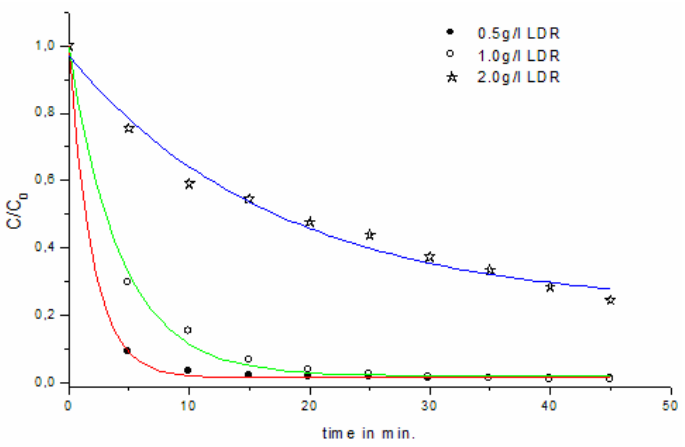

Fig. 7. Time dependence of decolorization of BDPT in the presence of surfactant Perigen LDR

\section{Decolorization of simulated wastewater and real industrial textile effluents}

In the next experiment an aqueous solution at the concentration of $200 \mathrm{mg} / \mathrm{dm}^{3}$ BDPT containing $80 \mathrm{~g} / \mathrm{dm}^{3} \mathrm{NaCl}$ and $0.5 \mathrm{~g} / \mathrm{dm}^{3}$ Perigen LDR, simulating the composition of real textile wastewater has been subjected to decolorization with Fenton's reagent. The doses of reagent amounting to 250, 350 and $500 \mathrm{mg} \mathrm{FeSO}_{4} / \mathrm{dm}^{3}$ with the ratio $\mathrm{FeSO}_{4}: \mathrm{H}_{2} \mathrm{O}_{2}=1: 10$ were used. As it is seen in Figure 8 , a satisfactory degree of color reduction above $97 \%$ both for $\mathrm{FeSO}_{4}$ dose 350 and $500 \mathrm{mg} / \mathrm{dm}^{3}$ was achieved.

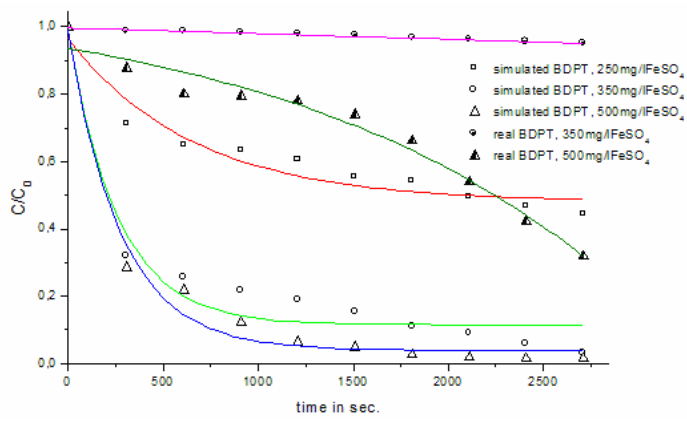

Fig. 8. Comparison of decolorization of simulated textile wastewater with real industrial wastewater at the same reagents concentration

Finally, the corresponding test for a real industrial wastewater after dyeing process with 350 and $500 \mathrm{mg} \mathrm{FeSO} / \mathrm{dm}^{3}$ and reagent ratio $\mathrm{FeSO}_{4}: \mathrm{H}_{2} \mathrm{O}_{2}=1: 10$, pH value equal to 3 was performed. Unexpectedly, the results of decolorization were incomparable with those obtained for the simulated wastewater. In the case of using $350 \mathrm{mg} \mathrm{FeSO} / \mathrm{dm}^{3}$ almost no color reduction was observed, however for $500 \mathrm{mg} \mathrm{FeSO} 4 / \mathrm{dm}^{3} 70 \%$ of color was reduced 
during $45 \mathrm{~min}$. It is difficult to explain these results of decolorization of real industrial wastewater which needs further investigation. One can conclude that simulated textile wastewater is not the same as real wastewater generated during reactive dying in industrial scale.

\section{Conclusions}

Fenton's reagent appeared to be a very effective method for the degradation of aqueous solution of many dyestuffs. Inhibition effect of $\mathrm{NaCl}$ present in textile wastewater on decolorization has been found: the higher content of $\mathrm{NaCl}$ the poorer the decolorization degree. Rate constants of the decolorization of selected dyes obtained by pulse radiolysis have shown that the reaction of chloride ion-radicals, which may be formed at high concentrations of $\mathrm{Cl}^{-}$, is slower than the reaction of hydroxyl radicals. The emulsification effect of surfactants present in textile wastewater at the concentration above the critical micelle concentration causes a decrease of decolorization rate.

Simulated textile wastewater is not the same with respect to decolorization by Fenton's reagent as real wastewater generated during reactive dyeing in industrial scale.

It was proved that nearly 5 times bigger reagent dose had to be used to decolorize a mixture simulating the composition of real textile wastewater than in the case of dyestuff solution without any additional substances. Moreover, to decolorize real wastewater generated in industrial reactive dyeing process $500 \mathrm{mg} \mathrm{FeSO}_{4} / \mathrm{dm}^{3}: 5000 \mathrm{mg} \mathrm{H} \mathrm{H}_{2} \mathrm{O}_{2} / \mathrm{dm}^{3}$ reagent dosage, ie nearly 7 times higher dose has to be applied than in the case of dyestuff solution.

It is justified to carry out further studies on the decolorization of model wastewater including dyestuffs, $\mathrm{NaCl}$, auxiliary agents and real wastewater, with Fenton's reagent as well as with other deep oxidation techniques.

\section{Acknowledgements}

The study was partially financed by the Polish National Centre for Research and Development, Project no. N R14 0038 06/2009.

\section{References}

[1] Czajkowski W. Nowoczesne barwniki dla włókiennictwa. Łódź; Wydawnictwo Politechniki Łódzkiej: 2006.

[2] Constapel M, Schellentrager M, Marzinkowski JM, Gäb S. Water Res. 2009;43:733-743. DOI: 10.1016/ j.watres.2008.11.006.

[3] Ahmed Nahed SE, El-Shishtawy Reda M. J Mater Sci. 2010;45:1143-1153. DOI: 10.1007/s10853-0094111-6.

[4] Xu Hang, Zhang Dongxiang, Xu Wenguo, J Hazard Mater. 2008;158:445-453. DOI: 10.1016/ j.jhazmat.2008.01.109.

[5] Papić S, Vujević D, Koprivanac N, Sinko D. J Hazard Mater. 2009;164:1137-1145. DOI: 10.1016/ j.jhazmat.2008.09.008.

[6] Kusić H, Loncarić BA, Koprivanac N, Papić S. Dyes Pigm. 2007;74:388-395. DOI: 10.1016/ j.dyepig.2006.01.050.

[7] Tantak NP, Chaudhari S. J Hazard Mater. 2006;B136:698-705. DOI: 10.1016/j.jhazmat.2005.12.049.

[8] Arslan-Alaton I, Gursoy Betul H, Schmidt J-E. Dyes Pigm. 2008;78:117-130. DOI: 10.1016/ j.dyepig.2007.11.001.

[9] Wang Shaobin, Dyes Pigm. 2008;76:714-720. DOI: 10.1016/j.dyepig.2007.01.012. 
[10] Gulkaya I, Surucu GA, Dilek FB. J Hazard Mater. 2006;B136:763-769. DOI: 10.1016/ j.jhazmat.2006.01.006.

[11] Bianco B, De Michelis I, Vegliň F. J Hazard Mater. 2011;186:1733-1738. DOI: 10.1016/ j.jhazmat.2010.12.054.

[12] Alnuaimi Maitha M, Rauf MA, Salman Ashraf S. Dyes Pigm. 2008;76:332-337. DOI: 10.1016/ j.dyepig.2006.08.051.

[13] Riga A, Soutsas K, Ntampegliotis K, Karayannis V, Papapolymerou G. Desalination. 2007;211:72-86. DOI: $10.1016 /$ j.desal.2006.04.082.

[14] Arslan-Alaton I, Tureli G, Olmez-Hanci T. J Photochem Photobiol A. 2009;202:142-153. DOI: 10.1016/ j.jphotochem.2008.11.019.

[15] Jayson GG, Parsons BJ, Swallow AJ. J Chem Soc Faraday Trans. 1. 1973;69:1597-1607. DOI: 10.1039/ F19736901597.

[16] Tehrani-Bagha AR, Mahmoodi NM, Menger FM, Desalination. 2010;260:34-38. DOI: 10.1016/ j.desal.2010.05.004.

[17] Ledakowicz S, Maciejewska R, Gebicka L, Perkowski J. Ozone: Sci Eng. 2000;22:195-205. DOI: $10.1080 / 01919510008547220$.

[18] Walling C. Acc Chem Res. 1975;8:125-131. DOI: 10.1021/ar50088a003.

\title{
ZASTOSOWANIE ODCZYNNIKA FENTONA DO OCZYSZCZANIA ŚCIEKÓW WŁÓKIENNICZYCH W WARUNKACH PRZEMYSŁOWYCH
}

\author{
${ }^{1}$ Wydział Inżynierii Procesowej i Ochrony Środowiska, Politechnika Łódzka \\ ${ }^{2}$ Instytut Włókiennictwa, Łódź
}

\begin{abstract}
Abstrakt: Stosowanie barwników reaktywnych jest bardzo popularne w przemyśle włókienniczym ze względu na fakt, że barwniki te charakteryzują się dobrą odpornością uzyskiwanych wybarwień. W 2009 roku Constapel et al oszacowali, że produkcja tego typu barwników sięga ponad $140000 \mathrm{Mg} / \mathrm{rok}$. Barwniki reaktywne są w większości $(50 \%)$ stosowane do barwienia włókien celulozowych, jednakże mogą one być również stosowane do wełny i poliamidu. Niestety, barwniki te mają niski stopień związania z włóknem $(50 \div 90 \%)$, co powoduje znaczące zabarwienie ścieków. Ponadto, proces barwienia wymaga stosowania: elektrolitów w postaci wodnych roztworów $\mathrm{NaCl}$ i $\mathrm{Na}_{2} \mathrm{SO}_{4}$ w stężeniu do $100 \mathrm{~g} / \mathrm{dm}^{3}$, środowiska zasadowego (pH > 10) i włókienniczych środków pomocniczych (w tym detergentów). Dlatego też ścieki wytwarzane podczas procesów barwienia reaktywnego charakteryzują się wysokim zasoleniem i pH oraz intensywnym zabarwieniem, a ze względu na niską wartość stosunku $\mathrm{BZT}_{5} / \mathrm{ChZT}$ nie są one biodegradowalne. Skuteczną metodą oczyszczania ścieków włókienniczych może być zastosowanie procesów pogłębionego utleniania (AOPs), wśród których odczynnik Fentona wydaje się być najbardziej obiecujący, gdyż jest najtańszy i łatwy w użyciu. Na podstawie najnowszych danych literaturowych stwierdzono, że w wielu badaniach z użyciem odczynnika Fentona zajmowano się głównie odbarwianiem roztworów barwników. Jednak zbyt mało uwagi poświęcono odbarwianiu rzeczywistych ścieków włókienniczych, zawierających barwniki, detergenty i sole $\left(\mathrm{NaCl}\right.$ i Na $\left.2 \mathrm{SO}_{4}\right)$. Eksperymenty przeprowadzone w skali laboratoryjnej były ukierunkowane na analizę inhibitującego wpływu $\mathrm{NaCl}$ i włókienniczych środków pomocniczych (środki dyspergujące i sekwestrujące) na proces odbarwiania odczynnikiem Fentona. Przedmiotem badań były syntetyczne ścieki symulujące skład rzeczywistych ścieków włókienniczych, jak również rzeczywiste ścieki powstałe w procesie barwienia reaktywnego. Wykazano zjawisko hamowania odbarwiania odczynnikiem Fentona w obecności $\mathrm{NaCl}$, a także środków powierzchniowo czynnych. Wykonano dodatkowe eksperymenty z wykorzystaniem radiolizy impulsowej w celu potwierdzenia wpływu obecności jonów chlorkowych na hamowanie procesu odbarwiania.
\end{abstract}

Słowa kluczowe: odczynnik Fentona, ścieki włókiennicze, odbarwianie, inhibicja 